\title{
Tourist's decision to travel to Thai cultural tourism destination in central part of Thailand
}

\author{
Nalin Simasathiansophon ${ }^{1, *}$, Chotima Jotikasthira ${ }^{2}$, Suraporn Onputtha ${ }^{2}$, \\ and Atchira Tiwasing ${ }^{2}$ \\ ${ }^{1}$ International College, Suan Sunandha Rajabhat University, Thailand \\ ${ }^{2}$ Rajamangala University of Technology Thanyaburi, Thailand
}

\begin{abstract}
The objectives of this study were to study the factors (personal factors and tourist's behaviours) affecting the tourists' decision to visit the cultural tourism. The samples were of 484 tourists visiting cultural attraction places in the central part of Thailand. The survey questionnaire was employed to use for data collection, with the purposiveness and convenience sampling method. Descriptive statistic with frequency, percentage, mean and standard deviation was used to analyze the data. Inferential statistic including independent-sample t-test and One-way ANOVA was used to test the hypotheses. The result indicated that personal factors including age and career affected the tourist's decision; meanwhile, gender, marital status and educational level did not affect the tourist's decision. Also, the tourist's behaviour including provincial destination, frequency of travelling, reason of travelling and accompaniers affected the tourist's decision at the significant level as of 0.05 . The result of the study can be useful for tourism entrepreneurs to set the appropriate cultural tourism activities for the tourist.
\end{abstract}

\section{Introduction}

The tourism industry is considered to be one of the main sources of Thai national income. The statistics from Office of Economic Affairs Tourism and Sports Ministry of Tourism and Sports [1] shows that the number of foreign tourists visiting Thailand in 2018 is approximately 38.27 million people, travelling from China, ASEAN countries, India, The United States and others which it generated 2.0 trillion baht. Addition, there are about 164.24 million Thai people visiting Thai tourism, which it also generated 1,068.20 billion baht in 2018. One of the most interesting tourism sectors, besides natural tourism, is "cultural tourism". Cultural Tourism is a tourism using culture and tradition of each country as a product to differentiate from other types of tourism, which adds value to tourist destinations [2]. Cultural tourism is accounted that it has a relatively high market value; its market size is the largest when compared to other forms of tourism. Regarding global level, the cultural tourism market is valued at approximately $\$ 900.00$ billion as well as it is expected to grow by $15 \%$ per year from 2014 to 2024 , worth $\$ 3,641.00$ billion.

\footnotetext{
* Corresponding author: nalin.si@ssru.ac.th
} 
Accordingly, it can be said that cultural tourism is highly attractive due to the large world market and high growth rates [3].

In Thailand, cultural tourism is also has significant effect on both domestic and international tourists' decision to visit. Most of the cultural tourism destinations can include historical sites (such as chapel, pagoda, and walls), museums or galleries, art performance events, special (local) lifestyles [4, 5, 6]. However, Thai tourism, comparing to other countries in the world, has less competitiveness, behind Japan, China, Myanmar, India and Cambodia, South Korea and Vietnam and others which the weakness point of Thai tourism is lack of Thainess and data linkage of Thai culture among the responsible organizations [3].

With the importance of cultural tourism being promoted and related issues, it is necessary for entrepreneurs needing to understand the factors affecting the tourists' decision to visit the cultural attraction places. Therefore, the researchers then are interested in studying the factors affecting tourist's decision in travelling to Thai cultural tourism in Bangkok and central part of Thailand in order to understand the personal factor and behaviour of the tourists playing significant roles in tourists' decision towards travelling to cultural tourism attraction places located in Bangkok and central part of Thailand. The benefits of this research can help the entrepreneurs effectively manage the activities related to culture and tradition, for examples, culture and tradition, local products, activities and tourism, house characteristics, tourist attraction, traditional foods and villagers' living for the tourists' expectation. In addition, the other stakeholders such as government can also utilize this study to help promote the cultural tourism.

\section{Research objectives}

In this study, the researchers established the research objectives as follows:

1) To study personal factors, tourist's behaviours and factors of tourists' decision.

2) To compare mean difference of factors of tourists' decision categorized by personal factors and tourist's behaviours.

\section{Research hypotheses}

In this study, the researchers can generate hypothesis as follows:

Hypothesis 1: Tourists with different personal factors in terms of gender, age, marital status, educational level and career had different opinion level about tourist's decision towards cultural tourism.

Hypothesis 2: Tourists with different behaviours in terms of provincial destination, frequency, reason, and accompaniers had different opinion level about tourist's decision towards cultural tourism. 


\section{Conceptual framework}

In this study, the researchers can draw the conceptual framework as follow.

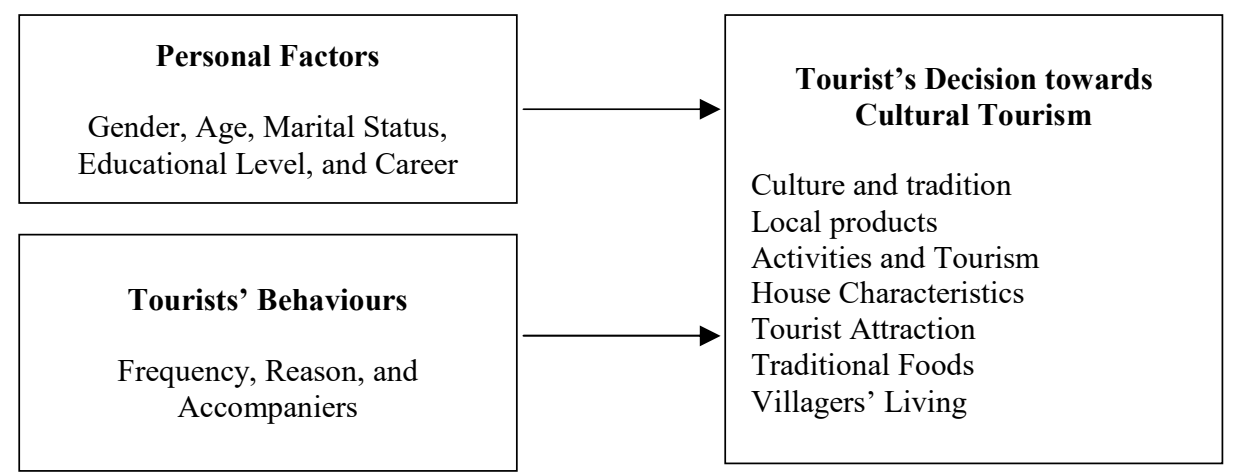

Fig. 1. Conceptual framework

\section{Literature reviews}

\subsection{Cultural tourism}

Lord [4] mentioned that the cultural tourism can be seen as the activities related to visiting historical sites, museums, or galleries, and attending related art performance events. In addition, it can also relate to activities about shopping, dining, and similar means created by mixing with community's culture. The UNESCO [5] also defined cultural tourism means travel concerned with experiencing cultural environments, including landscapes, the visual and performing arts, and special (local) lifestyles, values, traditions, events as well as other ways of creative and inter-cultural exchange processes. Kasamsuk, Bodthongtim and Sookprung [6] explored that the cultural tourism identity consists of architectural identity referring to chapel, pagoda, walls; painting identity referring to drawing in the temples telling the story of Buddha; sculptural identity referring to Buddha sculpture, angle and gods sculpture; historical identity referring the story of Buddha; and ritual and religious identity referring to Thai traditional dancing in Buddha days. Cultural tourism is important for various reasons; it has a positive economic and social impact, it establishes and reinforces identity, it helps build image, it helps preserve the cultural and historical heritage. With culture as an instrument, it facilitates harmony and understanding among people. In addition, it supports culture and helps renew tourism [5]. Lord [4] mentioned that the cultural tourism can provide a vehicle for cultural exchange and understanding, stimulate conservation and heritage preservation efforts, revitalizing traditional building and craft industries, generating economic activity and local or regional development and enhancing community cohesiveness and pride in cultural identity. However, cultural tourism can also have an negative effect on the cultural tourism including 1) culture becomes commercial, 2) environment is destructed, 3) there are more investments than conservation, 4) some architecture is not characteristics to local customs and 5) conflict sources and capacity problems [7]. A cultural attest is not a cultural tourism product unless it transforms itself into products that can be consumed by tourists [8, 9]. Monsef [10] studied about the cultural factors effecting tourism development in Ilam province, Iran, and found that cultural factors including language, customers, literature, architecture, ethnic diversity and religion can strengthen the cultural tourism development. Dachum [11] 
presented the ways to develop the cultural tourism in Thailand: 1) understand the identity and value of Thai culture; 2) search for the distinction of products and services; 3 ) understand the tourists and trend of cultural tourism; 4) enhance the community products and services, for examples, new packages, design or function, in order to gain added values; and 5) adjust and improve the marketing strategies to link traditional and modern marketing concepts to the cultural tourism management.

\subsection{Tourist's behaviour}

In order to satisfy tourists' cultural needs and wants, cultural tourism products typically attracts consumers by the cultural attributes. The behaviour of the cultural tourists can be divided into the general and specialized cultural tourists [12], which general tourists behaviour refers to the travelling to the cultural places for gaining new knowledge, experience, and interesting in the small cultural sites. Meanwhile, the specialized cultural tourist behaviour refers to the travelling to the different and various cultural sites for searching some board understanding of culture, history, and places. McKercher [13] divided the cultural tourists into 5 types including purposeful cultural tourist, sightseeing cultural tourist, serendipitous cultural tourists, casual cultural tourist, and incidental cultural tourist. Based on previous study, Liu and Lin [8] suggested that to respond the need of the tourists, the relevant persons need to create multiple cultural forms including high, popular, culture, learning and fun together in order to respond the different needs of tourists.

\subsection{Tourist's decision}

Chinnawongamorn [14] stated that the decision means choosing one of the many options after good consideration or assessment that is a way to achieve objectives. The process of decision-making can start from problem awareness, information search, alternative evaluation, purchase decision, and evaluation after purchase [15]. The study needs to understand the tourist's decision by considering the related factors. Factors affecting the decision of the tourists can be mentioned in many academicians. Silberberg [16] found that education level and income were associated with people who decided to visit the cultural sites. Zeppel [17] studied about the cultural tourism at the Cowichan native village in British Columbia and found that the retirees and teachers had more demand in visiting the cultural sites. Khodaverdizadeh [18] mentioned that education, age, income, marital status, and family size had an effect on decision to visit the cultural tourism. Abuamoud, Libbin, Green and ALRousan [19] studied the factors affecting the willingness of tourists to visit the cultural heritage sites in Jordan and found that education, variety of sites, multiple destination, cost and reason for visit can be the factors affecting the tourists' willingness. Choeichuenjit and Sapsanguanboon [2] explored such as tourist attraction, transportation, amenities, activities, personal expectation, advertising, and promotion, traveling experiences in the past, and word of mouth from friends/relatives can be the factors affecting the decision of the tourists. Moreover, Kasamsuk, Bodthongtim and Sookprung [6] explored the factors affecting the decision towards the cultural tourism can include tourism programs, selling channels, related organization collaboration, tour guide, personnel from tourism offices, facilities, safety and effects towards the cultural tourism. These factors are similar to the study result done by Kithwang [20]. In addition, to service people should consider quality and price $[21,22]$. Therefore, it can be advocated that the factors including personal characteristics, tourist behaviours, culture and tradition, housing styles, food, tourism attraction, and villager's living and local products can have an influence on decision-making. 


\section{Research methodology}

Population in this study are unknown number of tourists traveling to cultural tourism attraction places located in Bangkok and central parts of Thailand. The samples were calculated by unknown population and selected as of 384 tourists [23]. However, the researchers collected information from 484 tourists through self-reported questionnaire. The purposive and convenience sampling method were employed for data collection in this study.

In data collection, the researchers used close-ended questionnaires consisting of 3 parts. The first part is about the personal factors consisting of gender, age, marital status, educational level, and career. The second part is the tourists' behaviours consisting of provincial destination, frequency, reason, and accompaniers. These questions were the check-list question. The last part is the questions related to the five point rating scale asking about tourist's decision towards cultural tourism including culture and tradition, local products, activities and tourism, house characteristics, tourist attraction, traditional foods and villagers' living.

The sample questions used in this study can be such as: "There is a conservation of Thai tradition and culture", "There is a learning of provincial culture.", "There are OTOP selling.", "There are traditional products.", "There is a Thai drama.", "There is a Thai traditional play.", "The house is quiet.", "The house looks natural.", There is a museum displaying historical things.", "There is an ancient place.", "There is traditional food for particular province.", "There is a history of that particular province.", and "There is a traditional welcomeness.", as for examples.

The reliability with Cronbach's alpha higher than 0.80 was used to test the reliability of the questionnaire [24]. The study found that tourist's decision towards cultural tourism including culture and tradition, local products, activities and tourism, house characteristics, tourist attraction, traditional foods and villagers' living had Cronbach's alpha as of 0.886 , $0.922,0.881,0.806,0.885,0.840$ and 0.919 , respectively. The validity of questionnaire was also used by requesting the related researchers and expert's inspection to mark score on Item-Objective Congruence (IOC), the score must be higher than 0.70 . The acceptable results refer to the acceptable data for further analysis.

In terms of data analysis, the researchers analysed the data derived from samples by using descriptive and inferential statistics. The descriptive one including frequency and percentage was used to study personal factors and tourist' behaviour. In addition, the mean and standard deviation were used to study the opinion level of tourist's decision towards cultural tourism. The interpretation regarding the tourists' opinion was based on interpretation of Best and Kahn [25].

\section{Research results}

\subsection{General information of respondents}

The study from 484 respondents was found that the tourists travelling to cultural tourism attraction located in Bangkok and central parts of Thailand mostly were male $(83.3 \%)$ and female $(16.7 \%)$. Their age less than 20 years old $(0.2 \%), 21-30$ years old $(28.3 \%), 31-40$ years old $(55.0 \%)$ and more than 40 years old (16.5). In terms of marital status, they are single $(39.9 \%)$ and married $(60.1 \%)$. For educational level, they graduated lower than Bachelor's degree (54.5\%), Bachelors' degree (41.7\%), Master's degree $(3.3 \%)$, and higher than Master's degree $(0.4 \%)$. In terms of career, they are working as civil servants $(1.4 \%)$, 
traders $(11.2 \%)$, private business owner (2.5), unemployment (1.9\%), students $(4.3 \%)$, private company employees $(42.6 \%)$, and freelance $(36.2 \%)$.

\subsection{Tourists' behaviours}

The study was found that the respondents visit cultural tourism places one time a year $(8.1 \%)$, two times a year $(10.1 \%)$, three times $(9.9 \%)$ and more than three times a year (71.9). In terms of reasons of travelling, they intended to see and learn culture $(29.5 \%)$, to work $(28.5 \%)$, to visit relatives $(20.5 \%)$, to pass to another province $(9.7)$, to be recommended by known people $(5.8 \%)$, to be persuaded by advertisement $(2.9 \%)$, and other $(3.1 \%)$. In relation to people whom the travellers were accompanied with, the study found that they visited the cultural places alone (14.9\%), with family/relatives (48.8), with co-workers $(0.2 \%)$, with friends from school $(21.9 \%)$, with girlfriend/ boyfriend $(13.0 \%)$ and with unstated others $(1.2 \%)$.

\subsection{Opinion related to tourist's decision towards cultural tourism}

The study was found that the tourists travelling to cultural tourism attraction located in Bangkok and central parts of Thailand highly agreed towards the overall components of cultural tourism attraction with the mean score as of 3.599. When considering each components, the study found that tourists also highly agreed towards house characteristics, villagers' living, tourist attraction, culture and tradition, local products, traditional foods and activities and tourism with mean score as of 3.723, 3.633, 3.612, 3.590, 3.588, 3.580 and 3.464 , respectively.

\subsection{Hypothesis testing results}

Hypothesis 1: Tourists with different personal factors in terms of gender, age, marital status, educational level, and career had different opinion level about tourist's decision towards cultural tourism.

From the Table 1, it was found that tourists with different age had different opinion level about tourist's decision towards cultural tourism in terms of culture and tradition, local product, activities and tourism, traditional foods and overall with Sig. value equal to $0.003,0.002,0.001,0.046$ and 0.024 , respectively. Additionally, tourists with different career had different opinion level about tourist's decision towards cultural tourism in terms of culture and tradition and local product with Sig. value equal to 0.034 and 0.047 , respectively. Meanwhile, the tourists with other personal factors did not have different opinion level about tourist's decision towards cultural tourism at the statistically significant level as of 0.05 .

Hypothesis 2: Tourists with different behaviours in terms of provincial destination, frequency, reason and accompaniers had different opinion level about tourist's decision towards cultural tourism. 
Table 1. Independent-sample t-test and One-way ANOVA of Analysing Tourist's Decision Categorized by Personal Factors.

\begin{tabular}{|c|c|c|c|c|c|c|c|c|}
\hline \multirow[b]{2}{*}{ Personal Factor } & \multicolumn{8}{|c|}{ Tourist's Decision towards Cultural Tourism } \\
\hline & 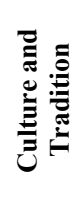 & 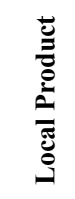 & 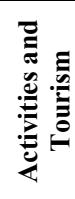 & 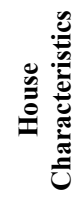 & 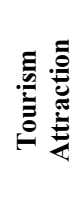 & 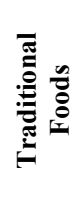 & 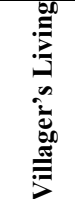 & $\begin{array}{l}\overline{\bar{\pi}} \\
\bar{\sigma} \\
\bar{\delta}\end{array}$ \\
\hline \multirow[t]{2}{*}{ Gender } & $\begin{array}{c}\mathrm{t}=- \\
0.998\end{array}$ & $\begin{array}{l}\mathrm{t}=- \\
1.451\end{array}$ & $\begin{array}{c}t=- \\
0.419\end{array}$ & $\begin{array}{c}\mathrm{t}=- \\
0.129\end{array}$ & $\begin{array}{c}t= \\
0.313\end{array}$ & $\begin{array}{l}t=- \\
0.509\end{array}$ & $\begin{array}{c}\mathrm{t}=- \\
0.053\end{array}$ & $\begin{array}{c}t=- \\
0.546\end{array}$ \\
\hline & $\begin{array}{l}\mathrm{Sig}= \\
0.319\end{array}$ & $\begin{array}{l}\mathrm{Sig}= \\
0.147\end{array}$ & $\begin{array}{l}\mathrm{Sig}= \\
0.676\end{array}$ & $\begin{array}{l}\mathrm{Sig}= \\
0.897\end{array}$ & $\begin{array}{l}\mathrm{Sig}= \\
0.754\end{array}$ & $\begin{array}{l}\mathrm{Sig}= \\
0.611\end{array}$ & $\begin{array}{l}\mathrm{Sig}= \\
0.958\end{array}$ & $\begin{array}{l}\text { Sig = } \\
0.585\end{array}$ \\
\hline \multirow[t]{2}{*}{ Age } & $\begin{array}{c}\mathrm{F}= \\
4.736\end{array}$ & $\begin{array}{c}\mathrm{F}= \\
5.000\end{array}$ & $\begin{array}{c}\mathrm{F}= \\
5.934\end{array}$ & $\begin{array}{c}\mathrm{F}= \\
0.107\end{array}$ & $\begin{array}{c}\mathrm{F}= \\
2.325\end{array}$ & $\begin{array}{c}\mathrm{F}= \\
2.682\end{array}$ & $\begin{array}{c}\mathrm{F}= \\
1.738\end{array}$ & $\begin{array}{c}\mathrm{F}= \\
3.159\end{array}$ \\
\hline & $\begin{array}{l}\text { Sig }= \\
0.003 \\
\end{array}$ & $\begin{array}{l}\text { Sig }= \\
0.002 \\
\end{array}$ & $\begin{array}{l}\text { Sig }= \\
0.001\end{array}$ & $\begin{array}{l}\text { Sig = } \\
0.956 \\
\end{array}$ & $\begin{array}{l}\text { Sig }= \\
0.074 \\
\end{array}$ & $\begin{array}{l}\text { Sig }= \\
0.046 \\
\end{array}$ & $\begin{array}{l}\text { Sig }= \\
0.158\end{array}$ & $\begin{array}{l}\text { Sig }= \\
0.024\end{array}$ \\
\hline \multirow[t]{2}{*}{ Marital Status } & $\begin{array}{c}\mathrm{F}= \\
0.327\end{array}$ & $\begin{array}{c}\mathrm{F}= \\
1.932 \\
\end{array}$ & $\begin{array}{c}\mathrm{F}= \\
2.247\end{array}$ & $\begin{array}{c}\mathrm{F}= \\
0.333 \\
\end{array}$ & $\begin{array}{c}\mathrm{F}= \\
0.021\end{array}$ & $\begin{array}{c}\mathrm{F}= \\
1.418 \\
\end{array}$ & $\begin{array}{c}\mathrm{F}= \\
0.810 \\
\end{array}$ & $\begin{array}{c}\mathrm{F}= \\
1.156\end{array}$ \\
\hline & $\begin{array}{l}\mathrm{Sig}= \\
0.567\end{array}$ & $\begin{array}{l}\mathrm{Sig}= \\
0.165\end{array}$ & $\begin{array}{l}\mathrm{Sig}= \\
0.135\end{array}$ & $\begin{array}{l}\mathrm{Sig}= \\
0.564\end{array}$ & $\begin{array}{l}\mathrm{Sig}= \\
0.886\end{array}$ & $\begin{array}{l}\text { Sig }= \\
0.234\end{array}$ & $\begin{array}{l}\text { Sig }= \\
0.368\end{array}$ & $\begin{array}{l}\text { Sig }= \\
0.283\end{array}$ \\
\hline \multirow[t]{2}{*}{$\begin{array}{c}\text { Educational } \\
\text { Level }\end{array}$} & $\begin{array}{c}\mathrm{F}= \\
1.578\end{array}$ & $\begin{array}{c}\mathrm{F}= \\
0.431\end{array}$ & $\begin{array}{c}\mathrm{F}= \\
0.202\end{array}$ & $\begin{array}{c}\mathrm{F}= \\
0.046\end{array}$ & $\begin{array}{c}\mathrm{F}= \\
0.459\end{array}$ & $\begin{array}{c}\mathrm{F}= \\
0.241\end{array}$ & $\begin{array}{c}\mathrm{F}= \\
1.085\end{array}$ & $\begin{array}{c}\mathrm{F}= \\
0.147\end{array}$ \\
\hline & $\begin{array}{l}\mathrm{Sig}= \\
0.194 \\
\end{array}$ & $\begin{array}{l}\mathrm{Sig}= \\
0.731\end{array}$ & $\begin{array}{l}\mathrm{Sig}= \\
0.895 \\
\end{array}$ & $\begin{array}{l}\text { Sig }= \\
0.987\end{array}$ & $\begin{array}{l}\text { Sig }= \\
0.711\end{array}$ & $\begin{array}{l}\mathrm{Sig}= \\
0.868 \\
\end{array}$ & $\begin{array}{l}\text { Sig }= \\
0.355\end{array}$ & $\begin{array}{l}\text { Sig }= \\
0.931\end{array}$ \\
\hline \multirow[t]{2}{*}{ Career } & $\begin{array}{c}\mathrm{F}= \\
2.292\end{array}$ & $\begin{array}{c}\mathrm{F}= \\
2.151\end{array}$ & $\begin{array}{c}\mathrm{F}= \\
1.771\end{array}$ & $\begin{array}{c}\mathrm{F}= \\
1.419\end{array}$ & $\begin{array}{c}\mathrm{F}= \\
1.916\end{array}$ & $\begin{array}{c}\mathrm{F}= \\
1.030\end{array}$ & $\begin{array}{c}\mathrm{F}= \\
1.186\end{array}$ & $\begin{array}{c}\mathrm{F}= \\
2.035\end{array}$ \\
\hline & $\begin{array}{l}\mathrm{Sig}= \\
0.034\end{array}$ & $\begin{array}{l}\mathrm{Sig}= \\
0.047\end{array}$ & $\begin{array}{l}\mathrm{Sig}= \\
0.103\end{array}$ & $\begin{array}{l}\mathrm{Sig}= \\
0.205\end{array}$ & $\begin{array}{l}\text { Sig }= \\
0.077\end{array}$ & $\begin{array}{l}\text { Sig }= \\
0.405\end{array}$ & $\begin{array}{l}\text { Sig }= \\
0.312\end{array}$ & $\begin{array}{l}\text { Sig }= \\
0.060\end{array}$ \\
\hline
\end{tabular}

Table 2. Independent-sample t-test and One-way ANOVA of Analysing Tourist's Decision Categorized by Tourists' Behaviours.

\begin{tabular}{|c|c|c|c|c|c|c|c|c|}
\hline \multirow[b]{2}{*}{$\begin{array}{c}\text { Tourists' } \\
\text { Behaviours }\end{array}$} & \multicolumn{8}{|c|}{ Tourist's Decision towards Cultural Tourism } \\
\hline & 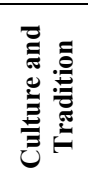 & 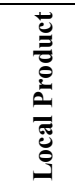 & 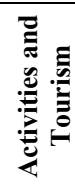 & 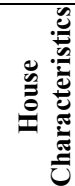 & 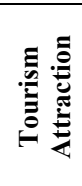 & 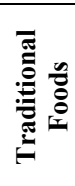 & 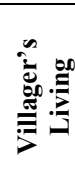 & $\begin{array}{l}\overline{\bar{\pi}} \\
\overline{0} \\
\delta\end{array}$ \\
\hline \multirow{2}{*}{$\begin{array}{c}\text { Provincial } \\
\text { Destination }\end{array}$} & $\begin{array}{c}\mathrm{F}= \\
1393\end{array}$ & $\begin{array}{c}\mathrm{F}= \\
1034\end{array}$ & $\begin{array}{c}\mathrm{F}= \\
1.445\end{array}$ & $\mathrm{~F}=$ & $\begin{array}{c}\mathrm{F}= \\
2726\end{array}$ & $\mathrm{~F}=$ & $\mathrm{F}=$ & $\mathrm{F}=$ \\
\hline & $\begin{array}{l}\mathrm{Sig}= \\
0.120\end{array}$ & $\begin{array}{l}\mathrm{Sig}= \\
0.420\end{array}$ & $\begin{array}{l}\mathrm{Sig}= \\
0.096\end{array}$ & $\begin{array}{l}\text { Sig }= \\
0.012\end{array}$ & $\begin{array}{l}\text { Sig }= \\
0.000\end{array}$ & $\begin{array}{l}1.404 \\
\text { Sig }= \\
0.089\end{array}$ & $\begin{array}{l}\mathrm{Sig}= \\
\mathrm{Sig}=\end{array}$ & $\begin{array}{l}\text { Sig }= \\
0.011\end{array}$ \\
\hline \multirow[t]{2}{*}{$\begin{array}{l}\text { Frequency of } \\
\text { travelling }\end{array}$} & $\begin{array}{c}\mathrm{F}= \\
1.283\end{array}$ & $\begin{array}{c}\mathrm{F}= \\
0.862\end{array}$ & $\begin{array}{c}\mathrm{F}= \\
1.823\end{array}$ & $\begin{array}{c}\mathrm{F}= \\
2.995\end{array}$ & $\begin{array}{c}\mathrm{F}= \\
0.758\end{array}$ & $\begin{array}{c}\mathrm{F}= \\
1.167\end{array}$ & $\begin{array}{c}\mathrm{F}= \\
1.511\end{array}$ & $\begin{array}{c}\mathrm{F}= \\
1.544\end{array}$ \\
\hline & $\begin{array}{l}\text { Sig }= \\
0.280\end{array}$ & $\begin{array}{l}\text { Sig }= \\
0.461\end{array}$ & $\begin{array}{l}\text { Sig }= \\
0.142\end{array}$ & $\begin{array}{l}\text { Sig }= \\
0.030\end{array}$ & $\begin{array}{l}\text { Sig }= \\
0.518\end{array}$ & $\begin{array}{l}\text { Sig }= \\
0.322\end{array}$ & $\begin{array}{l}\text { Sig }= \\
0.211\end{array}$ & $\begin{array}{l}\text { Sig }= \\
0.202\end{array}$ \\
\hline \multirow[t]{2}{*}{$\begin{array}{l}\text { Reason of } \\
\text { travelling }\end{array}$} & $\begin{array}{c}\mathrm{F}= \\
1.451\end{array}$ & $\begin{array}{c}\mathrm{F}= \\
1.744 \\
\end{array}$ & $\begin{array}{c}\mathrm{F}= \\
1.702 \\
\end{array}$ & $\begin{array}{c}\mathrm{F}= \\
2.652 \\
\end{array}$ & $\begin{array}{c}\mathrm{F}= \\
1.360\end{array}$ & $\begin{array}{c}\mathrm{F}= \\
2.994\end{array}$ & $\begin{array}{c}\mathrm{F}= \\
2.693 \\
\end{array}$ & $\begin{array}{c}\mathrm{F}= \\
2.558 \\
\end{array}$ \\
\hline & $\begin{array}{l}\text { Sig }= \\
0.194\end{array}$ & $\begin{array}{l}\text { Sig }= \\
0.109\end{array}$ & $\begin{array}{l}\text { Sig }= \\
0.119\end{array}$ & $\begin{array}{l}\mathrm{Sig}= \\
0.015\end{array}$ & $\begin{array}{l}\mathrm{Sig}= \\
0.229\end{array}$ & $\begin{array}{l}\text { Sig }= \\
0.007\end{array}$ & $\begin{array}{l}\mathrm{Sig}= \\
0.014\end{array}$ & $\begin{array}{l}\mathrm{Sig}= \\
0.019\end{array}$ \\
\hline \multirow[t]{2}{*}{ Accompaniers } & $\begin{array}{c}\mathrm{F}= \\
1.150\end{array}$ & $\begin{array}{c}\mathrm{F}= \\
1.351\end{array}$ & $\begin{array}{c}F= \\
0.297\end{array}$ & $\begin{array}{c}\mathrm{F}= \\
2.377\end{array}$ & $\begin{array}{c}\mathrm{F}= \\
0.622\end{array}$ & $\begin{array}{c}\mathrm{F}= \\
0.488\end{array}$ & $\begin{array}{c}\mathrm{F}= \\
1.308\end{array}$ & $\begin{array}{c}\mathrm{F}= \\
0.983\end{array}$ \\
\hline & $\begin{array}{l}\mathrm{Sig}= \\
0.333\end{array}$ & $\begin{array}{l}\text { Sig }= \\
0.241\end{array}$ & $\begin{array}{l}\text { Sig }= \\
0.915\end{array}$ & $\begin{array}{l}\mathrm{Sig}= \\
0.038\end{array}$ & $\begin{array}{l}\text { Sig }= \\
0.683\end{array}$ & $\begin{array}{l}\text { Sig }= \\
0.786\end{array}$ & $\begin{array}{l}\text { Sig }= \\
0.259\end{array}$ & $\begin{array}{l}\text { Sig }= \\
0.428\end{array}$ \\
\hline
\end{tabular}

From the Table 2, it was found that tourists with different provincial destination had different opinion level about tourist's decision towards cultural tourism in terms of house characteristics, tourism attraction; villager's living and overall with sig. value equal to $0.012,0.000,0.025$ and 0.011 , respectively. In addition, tourists with different frequency of 
travelling had different opinion level about tourist's decision towards cultural tourism in terms of house characteristics with Sig. value equal to 0.030. In addition, tourists with different reason of travelling had different opinion level about tourist's decision towards cultural tourism in terms of house characteristics, traditional foods, villager's living, and overall with Sig. value equal to $0.015,0.007,0.014$ and 0.019 , respectively. Lastly, tourists with different accompaniers had different opinion level about tourist's decision towards cultural tourism in terms of house characteristics with Sig. value equal to 0.038 . Meanwhile, the tourists with other tourists' behaviour did not have different opinion level about tourist's decision towards cultural tourism at the statistically significant level as of 0.05 .

\section{Discussion and conclusion}

In this study, the researchers established the research objectives and discussed the finding as follows:

In the study of personal factors, it was found that tourists travelling to cultural tourism attraction located in Bangkok and central parts of Thailand mostly were male, aged between 31 - 40 years old, were married, graduated lower than Bachelor's degree, and worked as private company employees. The reason is that the men need to drive the car for the women since some place is far from the home or staying places. In addition, the people with age between 31-40 years old are the ones who need to take their family to learn about the culture in order conserve the Thai wisdom. The result is in contrast with Zeppel [17] who studied about the cultural tourism at the Cowichan native village in British Columbia and found that the retirees and teachers had more demand in visiting the cultural sites. This contradicted result may be because the western culture would work harder in the normal life and spent time in more relaxed when retired.

In the study of tourists' behaviour, it was found that the tourists travelling to cultural tourism attraction located in Bangkok and central parts of Thailand mostly travelled to Bangkok, travelled for more than 3 times, with the purposes to visit the cultural places and went there with family/relatives. This is because Bangkok has many cultural sites since it has been the capital of Thailand and consists of many travelling place such as historic sites, museums or galleries, and cinema performing arts events, rivers and others. In addition, there are more about shopping, dining, and similar means created by mixing with community's culture such as Sam Yan market, Yoawarach market and others. This study matched with the study done by Lord [4] saying that cultural tourism can include both historical sites and commercial sites. Also, the study corresponds to the study done by the UNESCO [5] defining the cultural tourism can concern with experiencing cultural environments, landscapes, lifestyles, values, traditions, events as well as other ways of creative and inter-cultural exchange processes

In the study of the components of cultural tourism attraction, it was found that tourists travelling to cultural tourism attraction located in Bangkok and central parts of Thailand highly agreed towards house characteristics, villagers' living, tourist attraction, culture and tradition, local products, traditional foods and activities and tourism. This is because that the cultural tourism can encourage the tourists who visit the cultural sites can lean and understand the wisdom of Thailand and help maintain the culture which can represent the Thainess to the other people. This matched with Lord [4] mentioning that the cultural tourism can provide a vehicle for cultural exchange and understanding, stimulate conservation and heritage preservation efforts, revitalizing traditional building and craft industries, generating economic activity and local or regional development and enhancing community cohesiveness, and pride in cultural identity. In addition, the Thainess can represents in terms of house characteristics, villagers' living, tourist attraction, culture and 
tradition, local products, traditional foods and activities and tourism. The result of this study matched with the study done by Kasamsuk, Bodthongtim and Sookprung [6] explored the dimensions of Thai cultural tourism identity consisting of architectural identity, painting identity, sculptural identity, historical identity and ritual and religious identity.

In the hypothesis testing, it was found that tourists with different age had different opinion level about tourist's decision towards cultural tourism in terms of culture and tradition, local product, activities and tourism, traditional foods and overall. This is due to the different tourists with different age may demand different things. For examples, the young people may want to sightsee and enjoy the culture and tradition in terms of food, activities, and products. However, the old people may want to see and recall the experiences related to past experience. The study is matched with Khodaverdizadeh [18] who mentioned that education, age, income, marital status and family size had an effect on decision to visit the cultural tourism. Moreover, tourists with different career had different opinion level about tourist's decision towards cultural tourism in terms of culture and tradition and local product. This is because that the career can be related to the income that was obtained in each month, which it is useful when needing to travel far from home. The result is matched with Khodaverdizadeh [18] who mentioned that education, age, income, marital status and family size had an effect on decision to visit the cultural tourism.

In the hypothesis testing, it was found that tourists with different provincial destination had different opinion level about tourist's decision towards cultural tourism in terms of house characteristics, tourism attraction, villager's living. This is due to the different locations and places have different cultural components such as food, historical sites, pagoda, and man-made tourism. The result is corresponding to Monsef [10] revealing that cultural tourism development in Ilam province, Iran, consist of language, customers, literature, architecture, ethnic diversity and religion, which they are uniqueness. Furthermore, the study matched with Abuamoud, et al. [19] who studied the factors affecting the willingness of tourists to visit the cultural heritage sites in Jordan and found that education, variety of sites, multiple destination, cost and reason for visit can be the factors affecting the tourists' willingness. Furthermore, tourists with different frequency of travelling had different opinion level about tourist's decision towards cultural tourism in terms of house characteristics. The reason of this can be that when the place is beautiful and distinct will then bring tourist to visit again. The result is corresponding to Kasamsuk, Bodthongtim and Sookprung [6] exploring that architectural identity can help increase the tourists' interest. In addition, tourists with different reason of travelling had different opinion level about tourist's decision towards cultural tourism in terms of house characteristics, traditional foods and villager's living. This is because different people had different reason to visit the cultural purposes. Some people in some generation may demand to study and gain the experience; but some of them may just visit as general purposes. This is matched with the definition of Stebbins [12] mentioning that the type of cultural tourists can be both general tourists behaviour to gain new knowledge, experience; meanwhile, the specialized cultural tourist behaviour travelling to search for some board understanding of culture, history and places. Additionally, the study is matched with McKercher [13] mentioning that the cultural tourists into 5 types including purposeful cultural tourist, sightseeing cultural tourist, serendipitous cultural tourists, casual cultural tourist and incidental cultural tourist. Lastly, tourists with different accompaniers had different opinion level about tourist's decision towards cultural tourism in terms of house characteristics. This is because of that Thai culture is based on collectivism, which one can be persuaded when the group members mutually agree. The result is corresponding to Choeichuenjit and Sapsanguanboon [2] exploring that friends/relatives can be the factors affecting the decision of the tourists. 


\section{Recommendations}

\subsection{Recommendations from studies}

From the study, the researchers can recommend the following points:

1) The entrepreneurs and related persons should set the culture and tradition, local products, enjoyable activities and tourism, villagers' living display in order to serve the different aged tourists.

2) The entrepreneurs and related persons should conduct the activities related to culture and tradition and local product to attract tourists that have the career difference.

3) The entrepreneurs and related persons in each province should identify and create the own identity related to house characteristics, tourism attraction and villager's living since the tourists consider the destination to reach.

4) The entrepreneurs and related persons should create the activities related to the house characteristics and architectural distinct since the tourists will re-visit or not is depending on the house characteristics.

5) The entrepreneurs and related persons should provide the variety of house characteristics, traditional foods and villager's living in order to service the tourist who have different reason to arrive.

6) The entrepreneurs and related persons should differentiate the house characteristics and architectural distinct because it can differentiate the decision-making based on accompaniers, such as friends, family members, co-workers and so forth.

\subsection{Recommendations for future researches}

There have been limitations in this study; therefore, the future research can include as follows.

1) There should be a study of the marketing strategies, online marketing, service quality, tourism identity, and tourism management since the literature mentions the effect of mentioned variables on cultural tourism management and tourists' decision.

2) There should be a study implementing the quantitative techniques such as in-depth interview, observation, group discussion in order to gain the insight of information related to the decision-making toward the cultural tourism attraction.

\section{References}

1. Office of Economic Affairs Tourism and Sports Ministry of Tourism and Sports. Tourism Statistics System of Thailand. Supporting documents for the Tourism Statistics System Meeting of Thailand, 8 February 2019. (2018). https://www.mots.go.th/ewt_dl_link.php?nid=11321

2. W. Choeichuenjit, W. Sapsanguanboon, Jour. Tha. Hosp. Tour. 9, 2 (2014)

3. Effinity Company Limited. Project for Direction of Tourism Development in Thailand during the last 10 years (2016)

4. B. Lord, Cultural tourism and museums https://www.lord.ca/Media/Artcl_CltTourismMSeoulKorea_2002.pdf

5. UNESCO. Baltic Cultural Tourism Policy Paper (2004). https://unesco.lt/uploads/file/failai_VEIKLA/kultura/kulturinis_turizmas/Baltic_Cultur e_Tourism_Policy_Paper_Full_Document_Final_Checked.pdf 
6. S. Kasamsuk, M. Bodthongtim, W. Sookprung, Identity and cultural tourism business model for pilgrimage routes cultural in Ubon Ratchathani Province: A case of tour business Special Issue, 223-234 (2018).

7. J. Csapo, Strategies for tourism industry-micro and macro perspectives. InTech, 201232 (2012).

8. Y. D. Liu, C. F. Lin, Int. Mult. Jour. Tour. 6, 2 (2011).

9. Y. Zhang, Cultural Tourism Products: A Case Study in the Xi'an City (UNLV Theses, Dissertations, Professional Papers, and Capstones, 2011)

10. S. M. S. Monsef, Jour. Fund. \& App. Life Sc. 5, 1 (2015)

11. P. Dachum, Sil. Uni. Jour. 33, 2 (2013)

12. R. A. Stebbins, Ann. Tour. Res. 23, 4 (1996)

13. B. McKercher, H. Du Cros, Cultural tourism: The partnership between tourism and cultural heritage management (Routledge, 2002).

14. N. Chinnawongamorn, Airline Service Quality Strategy Influencing Decision Process in Choosing the International Airline Services at Suvarnabhumi Airport (Independent study, Master of Business Administration, Bangkok University, 2016)

15. S. Serirat, et al. Modern Marketing Management (Bangkok, Theera Film and Side Text Company Limited, 1998)

16. T. Silberberg, Tour. Mgmt. 16, 5 (1995)

17. H. Zeppel, Jour. Trav. Res. 41, 1 (2002)

18. M. Khodaverdizadeh, M. K. Kelas, Wor. Appl. Sci. Jour. 7, 4 (2009)

19. I. N. Abuamoud, J. Libbin, J. Green, R. ALRousan, Jour. Her. Tour. 9, 2 (2014)

20. Y. Kithwang, International Academic Conference on Educational \& Social Innovations on theme "Actual Economy: local solutions for global challenges", 387392 (2019).

21. K. Chienwattanasook, S. Onputtha, Jour. Mkt. \& Mgmt. 4, 2 (2017)

22. S. Jariyachamsit, Int. Aca. Res. Conf. Cop. (2019)

23. W. G. Cochran, Sampling Techniques ( $3^{\text {rd }}$ Ed) (New York: Wiley, 1977)

24. S. T. Hajiar, WSEAS Tran. Maths. 13 (2014)

25. W. J. Best, V. J. Kahn, Research in Education (10 Ed) (Boston: Allyn \& Bacon, 2006) 